\title{
KATARZYNA BRATNICKA
}

\author{
Creativity \\ and effectiveness \\ in organizations. \\ A new approach \\ to an old question'
}

Ph.D. Katarzyna Bratnicka University of Economies in Katowice Department of Entrepreneurship and Innovative Management

\section{Introduction}

Although interest in organizational creativity has grown dramatically in recent years a general multilevel theory has remained elusive and the study of creativity presents an enormous challenge since it is complex and multifaceted phenomenon. Organizational creativity is still a fuzzy concept that poses complicated cross-level issues for both researchers and managers. Pressures for continuous improvement and adaptation place an increasing emphasis on various multilevel and multidimensional links among organizational creativity and organizational effectiveness. However, there is little theoretical guidance as to how these outcomes materialize within organizations and even less direction on how to conceptualize, model and examine the effects of emergent and topdown processes. In this article I fill- to some degree- this gap.

A scientific definition of creativity describes the construct as generation of idea that is both

1 Artykuł został przygotowany w ramach projektu pt.: „Politykowanie organizacyjne. Treść, proces, kontekst i efekty", sfinansowanego ze środków Narodowego Centrum Nauki przyznanych na podstawie decyzji numer DEC-2013/11/B/HS4/00673. 
new and potentially useful toward accomplishing desired goals (Amabile, 1996, Mumford \& Gustafson 1988). The commonly accepted definition underscores that: "organizational creativity is the creation of a valuable, useful new product, service, idea, procedure or process by individuals working together in a complex social system" (Woodman, Sawyer \& Griffin 1993: p. 293). Although several definitions of creativity can be found in the organizational creativity literature, they are consensual in stressing that creativity implies novelty and usefulness (Liu, Bai, \& Zhang 2011).

Organizational creativity is defined as the ability of an organization to simultaneously generate both new and useful ideas, resulting from hosting multiple contradictory structures and processes within the same organization (Bratnicka 2014). Creative novelty and creative usefulness are separate independent activities that can be undertaken to a great extent without suffering in a loss in the other dimension, loading to an overall high level of organizational creativity. Moreover, I propose that usefulness can support novelty by improving organizational members' understanding of the organization's resources and capabilities required to fill "knowledge gaps" (Cao, Gedajlovic \& Zhan, 2009). Exploration of new ideas facilities creative usefulness by creating a larger set of routines and competencies to draw from. Both creative novelty and creative usefulness are crucial for long- term survival and success of organizations. Although vital, organizational creativity is difficult to achieve because its dimensions require very different organizational structures.

Consistent with Kaufman and Beghetto (2009), I suggest that creativity need not be thought of as extraordinary events, but should be thought of as regularly occurring possibilities in organizations. Sulivan and Ford (2010) empirically compare whether creativity is best assessed as an unidimensional construct or as a multidimensional construct. The results suggest that the measurement model with distinct formative indicators for novelty and usefulness represents creativity assessment better than one - and three - factor models. Sue-Chan and Hempel (2010) developed a new operationalization of creativity based on treatment of novelty and usefulness as two separate dimensions. Similarly, Choi (2004) and maintained that there are differences in both antecedents to, and consequences of, novelty and usefulness. Moreover, the different dimensions of creativity are likely to be differentially influenced by individual task and organizational elements. Hence, I consider the novelty and usefulness as two distinct dimensions of organizational creativity.

Multilevel research does not examine to emergence and shaping of organizational creativity directly, although it does examine whether 
aggregating individual perceptions or behaviours into a higher-level construct is justified. Thus, there are fundamental research questions that are currently unexplored in the literature. This represents a substantial gap in organizational science. Addressing these fundamental questions is relevant to advance theory and to develop interventions and tools to shape organizational creativity processes: (1) What are primary emergent processes that account for the organizational creativity?, (2) What top- management initiatives drive employees' interaction and exchange such that an organizational creativity as collective macrostructure manifests?

Theories of creativity typically emphasize the role of individuals and small group, with little or no recognition that creative activities might well beembedded in larger organizational processes. A review of academic literature in the areas of creativity, organization theory and strategic management reveals that research examining creativity in organizations is still in early stages, compared to the study of creativity at the individual and team level. However, some scholars observed the collective creativity process, where particular interactions yield creative insights, yet those insights cannot be attributed to particular individuals (Hargadon \& Bechky, 2006: 484). They strongly endorse that organization isn't just one-to-one environment, it is an interpersonal context in which different ideas influence and re-influence each other, and in which higher-order ideas influence the development of lower level ideas. Following this line of arguments, I propose that creative organizational activities should be assessed relative to an organization's current emergent processes and top- management initiatives.

The article is structured in three sections. I first briefly discuss the consequences of focus on composition and compilation forms of emergence as manifest by creative usefulness and creative novelty. Next, I argue that topdown management activity shaping organizational creativity are best capture by directing attention to autonomous resourcing and directed resourcing. In concluding this article I discuss key implications and offer avenue for future research.

\section{The framework of emergent processes of organizational creativity}

Social phenomena should be explained in terms of individuals plus social relations (Hodgson 2012). Many social theorists define social relations with structures. Relations and interactions involve a multiple layered ontology with emergent properties (Humphreys 1997). Organizational creativity emergent properties that render it additional units of analysis, while fully acknowledging 
that its very existence of creative teams depends upon creative individuals as well as existents creative organizations depends upon creative teams.

Building on the work of Allport (1954) and Katz and Kahn (1966), Kozlowski and Klein (2000: 55) define a phenomena as emergent when "it originates in the cognition, affects, behaviors, or other characteristic on individuals, is amplified by their interactions, and manifests as a higher level collective phenomenon". Drawing on complexity theory, Kozłowski et. al. (2013) specify three core conceptual foci to capture its essential nature: It is a multilevel, process oriented and temporal. First emergent phenomena are multilevel. They encompass at least two different levels of analysis, a lower level at which the phenomena originates and a higher level at which the collective property manifest. Shortly, emergent phenomena are multilevel, transcending their level of origin. They originate at lower level and emerge as a collective macrostructure at higher level. Manifestation of the collective property takes time, entailing developmental and episodic changes. Second, emergent phenomena are process oriented with emphasis on the dynamic interactive process mechanisms that drive the nature of, and forms of, emergence from lower to the higher. The substantive emphasis is on the mechanism that drive the dynamic interactions among entities that yield the emerged property. The process mechanism are theoretical engine of emergence; thus they need to be specified with precision. Researching emergence provides a window to begin mapping how such processes function. However, the fundamental process mechanism relevant to specific substantive phenomena would typically have to be elaborated in more precise detail. This particularly true for nonlinear compilations forms of emergence. Simple theories are likely to be easier to specify than complex theories. However, the key for specification is how well the theory- simple or complex- describes the underlying process of interaction and exchange. Third, emergent phenomena take time to manifest at the higher level. Time frames may be very brief or quite lengthy, depending on the phenomenon. Emergence take time to unfold and manifest. The more important focus of emergence is on process mechanism and dynamics: how lower level characteristics coalesce or diverge to create meaning full higher-level patterns.

Both composition and compilation models of emergence are essential for understanding how individual and team creativity connects to organizational outcomes. The difference between the two emergent processes is captured conceptually by three distinguished conditions (Kozlowski \& Klein, 2000). The first condition is whether individual contributions to a higher level phenomenon (in this case, a practice) are similar (isomorphic) or dissimilar (discontinuous). 
Kozlowski and Klein (2000) illustrate these differences in emergent process conditions by comparing the composition type of contributions to collective outcomes of a rowing crew (isomorphic) to the compilation emergent process of a symphony orchestra (discontinuity). The second condition is the differences between the dynamics and nature of the interaction processes. Composition forms of emergence tend to have stable processes that exhibit uniform patterns and demonstrate low dispersion (e.g., few differences across individuals). Compilation forms of emergence, in contrast, are irregular, high in dispersion, are rely on non-uniform patterns of interaction. Moreover, distinct combination rules which are relate to the fundamental nature of aggregation distinguish the two forms of emergence. Composition rules for isomorphic phenomena are generally based on additive or averaging models that combine similar individual contributions in linear convergent manner. Compilation forms of emergence are more complex and non-linear and generally aggregate in a more configurational or synergistic matter.

Usefulness practices focus on consistent repetition of established organizational activities and processes to benefit from using what is known. This creates an explicit set of rules and shared understanding among organization members. These rules and understanding can act as convergence mechanism that create shared beliefs and consistent mental models. As usefulness practices shift from being performed by an organization member to being performed as a team and an organization - the types of contributions made by each individual to team levels outcomes (and by each team to the organization level outcomes) need to remain very similar to maintain desired consistency and efficiency. Team (organization) effectiveness is maximized when the contribution of each member's (team's) input is aggregated in summative form. Regardless the differences in the level of effort or contribution, each organizational member's (team's) contribution will still act in a summative, linear manner.

Composition characteristics of emergent processes in exploitative settings contribute to achieving the desired high levels of consistency, accuracy, and reliability. The isomorphism characterizing organizational member's shared mental models ensure that interaction processes remain stable throughout the practice execution. This logic is captured in the following proposition.

Proposition 1. The closer the emergent processes are to compilation forms of emergence in creative usefulness activities, the higher the resulting organizational effectiveness will be.

In creative novelty, a very large volume of underlying information need to be mastered and processed to accommodate unexpected parameters and thereby 
achieved the desired customized effectiveness outcomes. In such settings, the generation and application of unique know-how with creative results is desirable. Common goals help to provide the focus, but similar mental models are not necessary and may be detrimental to the overall creative novelty process. That is, organizational effectiveness is maximized when the degree and nature of individual (team) contribution to the collective outcome is highly differentiated. Moreover, the desirable individual (team) effectiveness and contribution will be very different from the collective practice effectiveness. Mechanism to create compatible, but not shared, mental models that enable diverse domain to be integrated are typically required. With collective creative novelty practices organizational effectiveness is only achieved if each team (organization) member makes dissimilar contributions reflecting their particular creativity, but coordinates what they do with other members of the team (organization). As complexity and ambiguity requirements increase, organization (team) contributions and effectiveness are expected to be comparably different from team (individual) contributions and effectiveness. This variation is needed to accommodate and adapt complex requirements and unexpected parameters. In creative novelty, compilation forms of emergence will be more effective since this activity require discontinuous patterns during the emergence process. Hence, I suppose

Proposition 2. The closer the emergent processes are to compilation forms of emergence in creative novelty, the higher the resulting organizational effectiveness will be. In the following section, I scrutinize the research question of what is the nature of management processes shaping organizational creativity. I concentrate on specific creative resourcing explanation.

\section{The multilevel effects of the managing creative resourcing}

Echoing the calls from some years ago (Hitt, Beamish, Jackson \& Mathieu 2007; Kozlowski \& Klein 2000) for simultaneous investigation of both upward and reciprocal influences, I suggest that organizational creativity research could be enriched by reconciling these two logics. Bottom- up processes represent the aggregate influence of individuals- through social interaction, exchange, and amplification. These processes describe the manner in which lower- level properties (cognition, affect, behavior, values, or characteristics of individuals) emerge to form collective phenomena at higher levels. Top- down processes describe the influence of higher- order contextual factors which direct, shape or moderate factors on lower- level processes and outcomes. This logic is that the 
organizational context of accepting new and useful ideas as suitable within team and individual creative process are nested exerts a downward influence.

A basic tenet of arguments concerning the endogenous resourcefulness processes (Dutton et al. 2006; Glynn \& Wrobel 2006) is that employees generate new resources within organizations, and these resources in turn help to propel further action (e.g., Quinn \& Worline 2008). Creative resourcing may help employees develop a repertoire of actions to solve subsequent problems, grounding a strategic advantage in transforming common objects into something distinctive (e.g., Nag \& Gioia 2012). An important aspect of creative resourcing is that it depicts the creative process as paradoxically involving permission and guidance, something scholars have proposed as being crucial for the organizational creativity (e.g., Locke, Golden-Biddle, \& Feldman 2008).

I now describe how Sonnenshein (2014) findings contribute to multilevel research on organizational creativity. He indentify two core organizational processes (autonomous resourcing and directed resourcing) that explain how organizations foster ongoing creative activities in response to different perceived resource endowments by focusing on critical organizational processes that connect resources and creativity over time. Explaining how individuals creatively act on objects to turn them into resources, and how managers facilitate this process has important implication for multilevel creativity research. While only tentative, these findings suggest a shift from a unitary view of creativity, popular among scholars, in which similar process explain both novelty and usefulness dimensions of creativity (George, 2007; Unsworth 2001). The shift here is also one of needing to move from an emphasis on the exogenous environment to the endogenous, growth and enabling constraints provided by an organization (Felin 2012)

What is important for autonomous resourcing is that managers interpret a limited resource endowment and attempt to cultivate widespread creative action to cope with this endowment. But a consequence of this approach is that, once started, managers have relatively little control over how creative resourcing unfolds-something that leads to original solutions often not imaginable by managers. In contrast to autonomous resourcing, directed resourcing involves greater ongoing managerial control over creative resourcing. The central mechanism in directed resourcing is managers' regulation of objects. The fact that the central mechanism of directed resourcing emanates from how managers withhold and provision objects leads to greater managerial control compared with autonomous resourcing. 
It is important to note that this distinction of organizational creativity process advance research around how top-down organizational processes shape and generate the classics dimensions of creative novelty and creative usefulness that both constitute and generate organizational creativity. While somewhat speculative, solutions from directed resourcing may favor creative usefulness more than novelty as managers exert greater control over the organizational creativity process. At the same time, solutions from autonomous resourcing may facilitate creative novelty more than creative usefulness, because employee manipulations and recombinations are new; they are neither provided by managers nor by other sources. Put in more generally, bottom-up creative novelty process parallels to autonomous resourcing, and top-down creative usefulness process parallels to directed resourcing.

Based on these arguments, I propose the following propositions:

Proposition 3. The closer the management processes are to autonomous resourcing in creative novelty, the higher the resulting organizational effectiveness will be.

Proposition 4 . The closer the management processes are to directed resourcing in creative usefulness, the higher the resulting organizational effectiveness will be.

\section{Discussion}

Organizational creativity activities not only have an impact on the effectiveness and efficiency of practices, but also can shape the way in which emergence takes place. As discussed previously, composition forms of emergence are characterized by similarity in attributes and contributions from individuals, stable processes, uniforms interaction patterns, and aggregation that reflects linear additive or averaging processes. Compilation forms emergence, in contrast, are characterized by diverse attributes and discontinuous contributions from individuals, irregular processes, shifting patterns of interaction, and synergistic aggregation.

Achieving outcomes that demonstrate synergy and versatility enable organizations to meet the needs of a variety of stakeholders but also create an organization that is increasingly challenging to manage. While emergence cannot be comprehensively directed and controlled, it is neither random nor entirely beyond influence. Emergent processes can be actively shaped and controlled. 
The multilevel framework provides useful lens for gaining insight into the black box of creativity top- down shaping in organizations. Both autonomous and directed resourcing models influence the way in which novelty and usefulness is augmented through various social exchanges to form collective behavior or practices. I propose a continuum of creative resourcing with the endpoints representing two opposite forms: novelty and usefulness. These two forms are very different processes that lead to fundamentally distinct outcomes. These forms of creative resourcing have theoretical assumptions that are essential to understanding the relation between creative novelty and creative usefulness. My expectation is that organizational processes should vary with specific practice types, that is creative novelty or creative usefulness.

Top management initiatives that focus on control, routines, procedures, and efficiency will shape practices to have composition form of emergence since they constrain variation, while encouraging stable processes and uniform patterns. In contrast to top management initiatives that encourage composition, other initiatives that focus on collaboration capabilities, information synthesis, new idea generation will shape practices to have compilation forms of emergence since they enable irregular processes and shifting patterns to be tried.

Finally, I believe further research extend my model of organizational creativity and organizational effectiveness by identified a key boundary condition of my presumed casual sequence. Strategic management theorists typically develop their perspectives under the assumption of high environment dynamism, hostility, and complexity. Moreover, such environment has also been highlighted as a key contextual moderator in creativity literature (Taggar 2002). In essence, I proposed to examine the boundary condition of the organizational creativity and organizational effectiveness link, by testing this assumption in the literature, namely, that creative potential can be more effective mobilize in dynamic, hostile, complex environment. I hope the answers will provide further impetus to continue the journey of advancing our understanding of organizational creativity.

From a system view creativity is a process arising out of interactions in a given system (Montuori 2011). Theories of creativity typically emphasize the role of individuals or teams, with little or no recognition that creative processes may well be embedded in larger organizational efforts entailing interdependencies between units or across complex organizational systems (Kazanjian, \& Drazin 2012). Thus far, however, the literature has not fully acknowledged the use of organizational creativity as a strategic tool and has fallen short of comprehensively explaining the purposeful design embodying creativity. 
In complex organizational settings, the central challenge of exploring and exploiting the potential of organizational creativity as strategic asset is to provide organizational mechanisms that facilitate active engagement of individuals, teams and whole organization in the creative process.

Wellman (1983) argues that the lens of social network analysis shifts attention away from seeing the world from vantage point of two-person ties that are largely voluntary and equal in power, and introduces a way of seeing organizational realities from the perspective of asymmetric, hierarchical and systematic structures. I suggest that multilevel organization phenomena also may be understood by examining the web of relationships in which they are embedded rather than focusing exclusively on dyadic or linear connections. As we expand our understanding of different forms of emergence, we become better able to understand and predicts the nature of interdependce among multilevel phenomena. Some aspects of lower level phenomena are likely to be replicated in a fairy linear manner within higher level systems and some aspects of lower level phenomena are expected to change rather dramatically as they emerge across levels. The discussion put forward in this paper contribute an important step toward capitalizing on the conceptual benefits introduced by the lens of emergence and creative resourcing.

\section{Conclusion}

I examine creativity as multilevel phenomenon and theorize on the dynamics of bottom up emergence of creativity-in-practice and top-down contextual factors that help to shape organizational practices. Thus, I take an initial step toward understanding and articulating these complicated relations so that managers and scholars can design better ways to meet the challenges of a contemporary management.

\section{Summary}

Creativity and effectiveness in organizations. A new approach to an old question

Juxtaposing the important insights of previous multilevel research, the following overarching question emerges as the central concern of this article: How do emergent processes and top- management initiatives affect the impact of organizational creativity on organizational effectiveness? To shed light on this question, I direct attention to bottom- up emergent processes and top- 
down management initiatives, which, I argue, offers important opportunities for the genesis of additional creativity effects.

In all, the purpose of this article has been to address to recent theories and debates about the nature of organizational creativity and to highlight the crude beginnings of an alternative, multilevel approach. I explore how the dimensions of organizational creativity generated through emergent processes and top management initiatives plays a significant role in the leveraging organizational effectiveness.

Keywords: organizational creativity, multilevel approach, emergent processes, creative resourcing.

\section{Streszczenie}

Twórczość i efektywność w organizacjach. Nowe podejście do starego pytania

Celem niniejszego artykułu jest znalezienie odpowiedzi na pytanie jak emergentne procesy i inicjatywy kadry zarządzającej wpływają na oddziaływanie twórczości organizacyjnej na efektywność organizacyjną? Wykorzystując dotychczasowy dorobek badań wielopoziomowych, skoncentrowano uwage na oddolnych procesach emergencji i odgórnych inicjatywach menedżerskich, które oferują dodatkowe możliwości wzrostu efektów twórczości organizacyjnej. Ogólniej biorąc, odwołano się do współczesnych teorii i dyskusji odnoszących się do natury twórczości organizacyjnej i zarysowano wstępnie nowe podejście teoretyczne. W szczególności wyjaśniono, rolę procesów emergencji i inicjatyw kadry zarządzającej w podwyższaniu efektywności organizacyjnej zarówno w wymiarze twórczej nowości, jaki twórczejużyteczności.

\section{Słowa}

kluczowe: twórczość organizacyjna, ujęcie wielopoziomowe, procesy emergencji, twórcze kształtowanie zasobów.

\section{References}

1. Allport F. (1954), The structuring of events: Outline of a general theory with applications to psychology, "Psychology Review", 61: 281-303.

2. Amabile T.M. (1996), Creativity in context: Update to the social psychology of creativity, Westwiev, Boulder. 
3. Cao Q., Gedajlovic E., \& Zhan H. (2009), Unpacking organizational ambidexterity: Dimensions, contingencies, and synergistic effects, "Organization Science", 20: 781-796.

4. Choi J.N. (2004), Person-environment fit and creative behavior. Different impacts of supplies-values and demand-abilities version of fit, "Human Relations", 57: 531-552.

5. Dutton J. E., Worline M. C., Frost P. J., \& Lilius J. (2006), Explaining compassion organizing, "Administrative Science Quarterly", 51: 59-96.

6. Felin T. (2012), Cosmologies of capability, markets, and wisdom of crowds: Introduction and comparative agenda, "Managerial and Decision Economics", 33: 283- 294.

7. George J.M. (2007), Creativity in organizations, "The Academy of Management Annals", 3:439-477.

8. Glynn M.A., \& Wrobel K. (2006), My family, my firm: How family relationships function as endogenous organizational resources, in J. Dutton \& B. Ragins (Eds.), Exploring positive relationships at work: Building a theoretical and research agenda: 307-324. Lawrence Erlbaum, Mahwah, NJ.

9. Hargadon A.B., \& Bechky B.A. (2006), When collections of creatives become creative collectives: A field study of problem solving at work, "Organization Science", 17: 484-500.

10. Hitt M.A., Beamish P.W., Jackson S.E. \& Mathieu J.E. (2007), Building theoretical and empirical bridges across levels: Multilevel research in management, "Academy of Management Journal", 50: 1385 - 1399.

11. Hodgson G.M. (2012), Meanings of methodological individualism, "Journal of Economic Methodology", 14: 211-26.

12. Humphreys P. (1997), How properties emerge, "Philosophy of Science", 64: 53-70.

13. Katz D. \& Kahn R.L. (1966), The social psychology of organizations, Wiley, New York.

14. Kaufman J.C., \& Beghetto R.A. (2009), Beyond big and little: The four C model of creativity, "Review of General Psychology", 13: 1-12.

15. Kazanjian R.K., \& Drazin R. (2012), Organizational learning, knowledge management and creativity, in M.D. Mumford (Ed.) Handbook of Organizational Creativity, 547-568. Academic Press/Elsevier, London/Waltham/San Diego.

16. Kozlowski S.W.J., \& Klein K.J. (2000), A multilevel approach to theory and research in organizations: Contextual, temporal, and emergent processes, in K. J. Klein \& S. W. J. Kozlowski (Eds.), Multilevel theory, research and methods in organizations: Foundations, extensions, and new directions: 3-90). Jossey-Bass, San Francisco, CA.

17. Kozlowski S.W.J., Chao G.T., Grand J.A., Braun M.T., \& Kuljanin G. (2013), Advancing multilevel research design: Capturing the dynamics of emergence, "Organizational Research Methods", 16: 581-615. 
18. Locke K.D., Golden-Biddle K., \& Feldman M.S. (2008), Making doubt generative: Rethinking the role of doubt in the research process, "Organization Science", 19: 907-918.

19. Liu X., Bai Y., \& Zhang R. (2011), Development and validation of the organizational creativity inventory in a Chinese context. Paper presented at the annual meeting of the Academy of Management, San Antonio.

20. Montuori A. (2011), Systems approach, in M. Runco \& S. Pritzker (Eds.), The encyclopedia of creativity: 414-421. Elsevier, Amsterdam.

21. Mumford M.D., \& Gustafson S.B. (1988), Creativity syndrome: Integration, application, and innovation, "Psychological Bulletin", 103: 27-43.

22. Nag R., \& Gioia D.A. (2012), From common to uncommon knowledge: Foundations of firm-specific use of knowledge as a resource, "Academy of Management Journal", 55: 421-457.

23. Quinn R.W., \& Worline M.C. (2008), Enabling courageous collective action: Conversations from United Airlines flight 93, "Organization Science", 19: 497- 516.

24. Sonnenshein S. (2014), How organizations foster the creative use of resources, "Academy of Management Journal", 57: 814-848.

25. Sue-Chan C., \& Hempel P.S. (2010), Disentangling the novel from the useful. Paper presented at the annual meeting of the Academy of Management, Montreal.

26. Sulivan D.M., \& Ford C.M. (2010), The alignment of measures and constructs in organizational research: The case of testing measurement models of creativity, "Journal of Business and Psychology", 25: 505-521.

27. Taggar S. (2002), Individual creativity and group ability to utilize creative resources: A multilevel model, "Academy of Management Journal", 45: 315330.

28. Unsworth K. (2001), Unpacking creativity, "Academy of Management Review", 26: 289-297.

29. Wellman B. (1983), Network analysis: Some basic principles, "Sociological Theory", Vol. 1 (1983), 155-200

30. Woodman R.W., Sawyer J.E., \& Griffin R.W. (1993), Toward a theory of organizational creativity, "Academy of Management Review", 18: 293-321. 